\title{
Correction to: Expanding Antimicrobial Stewardship to Urgent Care Centers Through a Pharmacist-Led Culture Follow-up Program
}

Lisa E. Dumkow $\cdot$ Thomas S. Beuschel $\cdot$ Kasey L. Brandt

Published online: October 25, 2017

(c) The Author(s) 2017. This article is an open access publication

Correction to: Infect Dis Ther (2017) 6:453-459

DOI 10.1007/s40121-017-0168-8

In the original publication, the data labels have been inverted in Figure 1. The corrected figure is given here.

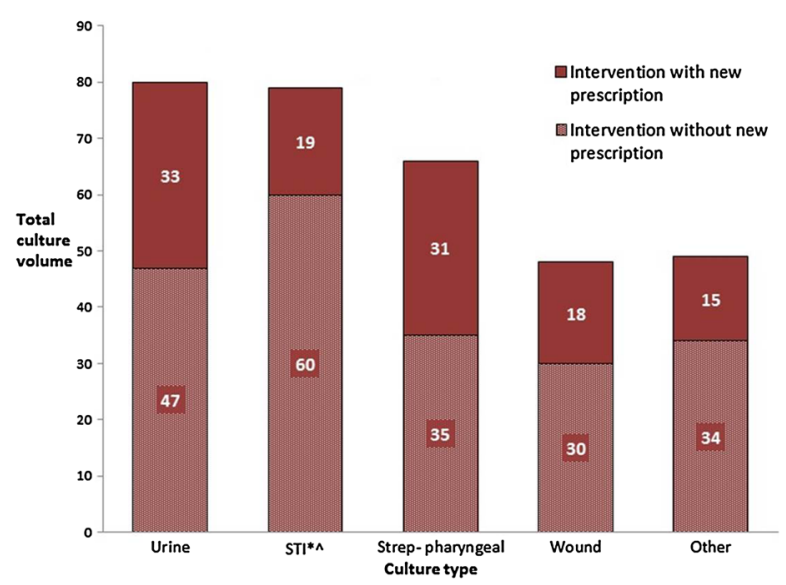

Fig. 1 Cultures requiring interventions and new prescriptions. *STI-sexually transmitted infection; ${ }^{\wedge}$ STI numbers do not include HSV

The online version of the original article can be found under doi:10.1007/s40121-017-0168-8.

L. E. Dumkow $(\bowtie) \cdot$ T. S. Beuschel · K. L. Brandt Department of Pharmacy Services, Mercy Health Saint Mary's, Grand Rapids, MI, USA e-mail: lisa.dumkow@mercyhealth.com

\section{OPEN ACCESS}

This article is distributed under the terms of the Creative Commons Attribution-NonCommercial 4.0 International License (http:// creativecommons.org/licenses/by-nc/4.0/), which permits any noncommercial use, distribution, and reproduction in any medium, provided you give appropriate credit to the original author(s) and the source, provide a link to the Creative Commons license, and indicate if changes were made. 